Original Article

\title{
ROYAL JELLY ALIPHATIC ACIDS CONTRIBUTE TO ANTIMICROBIAL ACTIVITY OF HONEY
}

\author{
Walerij Isidorov ${ }^{1 *}$ \\ Stanisław Witkowski \\ Piotr Iwaniuk ${ }^{3}$ \\ Monika Zambrzycka³ \\ Izabela Swiecicka ${ }^{3}$ \\ ${ }^{1}$ Forest Department, Bialystok University of Technology, Poland \\ ${ }^{2}$ Department of Natural Product Chemistry, Institute of Chemistry, Białystok \\ University, Poland \\ ${ }^{3}$ Department of Microbiology, Institute of Biology, Białystok University, Poland \\ *corresponding author: isidorov@uwb.edu.pl \\ Received: 13 November 2017; accepted: 10 May 2018
}

A bstract

Honey is valued for its therapeutic qualities which are attributed among others to its antibacterial multifactorial properties. However, all the factors that influence these properties have not been identified. The present study is focused on the antibacterial action of fatty acids originating from royal jelly, the larval food of honeybees. Aliphatic C8C12 acids characteristic of this bee product had previously been identified in more than fifty different samples of honey originating from seven countries and in eleven samples of Polish herbhoney. Experiments were performed to ascertain the influence of acidity on the antimicrobial activity of the acids. In acidic nutrient media all tested aliphatic hydroxyacids and unsaturated dicarboxylic acids demonstrated antibacterial action against different microbes with minimal inhibitory concentrations between 0.048 and $3.125 \mathrm{mM}$. Our results confirm that part of the antibacterial activity of honey contributes to these compounds of bee origin.

Keywords: antimicrobial activity, honey, royal jelly acids

\section{INTRODUCTION}

Owing to antimicrobial and wound healing properties, honey is also widely used in apitherapy (Mizrahi \& Lensky, 1996; Moore et al., 2001; Kwakman et al., 2010a; Al-Waili et al., 2011; Giles \& Laheij, 2017). There has been an upsurge of interest in the use of honey to control the growth of foodborne pathogens (Taormina, Niemira, \& Beuchat, 2001; Fidaleo, Zuorro, \& Lavecchia, 2010; Lee \& Lee, 2016). The antibacterial action of honey is attributed to high osmolarity, as well as to the content of methylglyoxal, MGO (Weston, Brocklebank, \& Lu, 2000; Mavric et al., 2008; Sultanbawa et al., 2015), the bee protein defensin-1 (Valachová, Bučeková, \& Majtán, 2016), phenolic acids (Aljadi \& Yusoff, 2003) and hydrogen peroxide (Brudzinski, 2006; Brudzinski et al., 2011; Brudzinski \& Sjaarda,
2015; Brudzinski et al., 2017; Grecka et al., 2018). Besides these well characterized antibacterial factors, honey is thought to contain other unknown compounds with bacteriostatic or bactericidal activity (Kwakman et al., 2010b; Al-Waili et al., 2011; Bučeková \& Majtán, 2016; Fyle et al., 2017). This belief is based on the preservation of antibacterial activity by honey after the successive neutralization of $\mathrm{H}_{2} \mathrm{O}_{2}, \mathrm{MGO}$ and defensin-1 (Kwakman et al., 2010a). Moreover, Bogdanov (1997) concluded that the high "residual" activity of honey was associated with its acidic fraction and was of bee origin.

The acidic components of bee origin are represented in honey solely by the set of $\mathrm{C}_{8}, \mathrm{C}_{10}$ and $\mathrm{C}_{12}$ hydroxy fatty acids and unsaturated dicarboxylic acids typical of royal jelly(RJ) (Isidorov et al., 2009; Isidorov et al., 2011). A long time ago, Blum, Novak, \& Taber (1959) determined that 
the main RJ acid, 10-hydroxy-2(E)-decenoic acid (10-HDA), possessed antibacterial activities. According to these authors, 10-HDA was less than one fourth as active as penicillin against Micrococcus pyrogenes and less than one fifth as active as chlortetracycline against Escherichia coli. The main goal of the present study was to evaluate the antibacterial activity of some of the $\mathrm{RJ}$ acids against a wide range of microorganisms, which had not been previously investigated. The inhibitory spectra of these acids were compared with the antimicrobial activity of acidic fraction extracted from lyophilised royal jelly.

\section{MATERIAL AND METHODS}

\section{Materials}

10-Hydroxy-Z(E)-decenoic and 2-dodecene-1,12dioic (2-DDecDA) acids were purchased from Cayman Europe (Tallinn, Estonia). 2-Hydroxyoctanoic (2-HO-C8), 8-hydroxyoctanoic (8-HO-C8), 9-hydroxydecanoic (9-HDAA), 10-hydroxydecanoic (10-HDAA) and 12-hydroxydodecanoic (12-HDAA) acids, and bis(trimethylsilyl)trifluoroacetamide (BSTFA) with added $1 \%$ trimethylchlorosilane were purchased from Sigma-Aldrich (Poznań, Poland). A commercial preparation of lyophilized royal jelly (lot 01032014) was obtained from Bartpol (Poland). The genuine multifloral honey was supplied by Bartnik Sądecki' (Stróże, Poland) and pine herbhoney by Doctor Miodek ${ }^{\text {Th }}$ (Białystok, Poland).

\section{Synthesis of dec-2(E)-ene-1,10-dioic acid}

Dec-2(E)-ene-1,10-dioic acid (2-DecDA) was obtained by the oxidation of 10-HDA with pyridinium dichromate (PDC) according to the method by Corey \& Schmidt (1979). Commercial 10-HDA (74.4 mg, $0.4 \mathrm{mM}$ ) and $526 \mathrm{mg}$ of PDC was dissolved in $3 \mathrm{~mL}$ of dry dimethyl formamide and stirred at ambient temperature under argon overnight. Water $(5 \mathrm{~mL})$ was next added and extracted with diethyl ether $(3 \times 5 \mathrm{~mL})$. The combined extracts were washed with saturated $\mathrm{NH}_{4} \mathrm{Cl}$ solution and water. After anhydrous $\mathrm{Na}_{2} \mathrm{SO}_{4}$-drying and evaporation to dryness, the crude solid product was purified through column (silica, ethyl acetate) chromatography. Fifty-five milligrams of crystalline 2-DecDA was obtained (69\% yield with a melting point of $166-169^{\circ} \mathrm{C}$ ).

\section{Extraction and analysis of lyophilized royal jelly}

The sample preparation and GC-MS investigation of RJ acidic fraction were performed as previously described (Isidorov et al., 2009). In short, the friable contents of five capsules of Bartpol Iyophilized royal jelly with a total mass of $505 \pm 10 \mathrm{mg}$ was transferred to a retort and extracted $(3 \times 25 \mathrm{~mL})$ with diethyl ether. The joint extracts were filtered, and the solvent was removed at $50{ }^{\circ} \mathrm{C}$. The residue left on the walls $(140 \pm 5 \mathrm{mg})$ was washed with $10 \mathrm{~mL}$ of ether (extractions were performed in triplicates); 0.5 $\mathrm{mL}$ of this solution was evaporated and derivatized by BSTFA in dry pyridine. The trimethylsiIyl (TMS) derivatives were analysed by capillary GC on a HP 7890A gas chromatograph with a 5975C VL MSD mass selective detector (for more details and chemical composition of the extract. see the Supplementary Online Material).

To identify the separated components, both mass spectral data and calculated linear temperature-programmed retention indices $(/ /)$ were used. Mass spectrometric identification was carried out with an automatic GC-MS data processing system supplied by NIST as well as with the authors' previously published data (Isidorov et al., 2009; Isidorov et al., 2011; Isidorov, Bakier, \& Grzech, 2012; Isidorov et al., 2015; Isidorov, 2015).

\section{Extraction and analysis of honey}

Acidic compounds were extracted from both genuine honey and herbhoney as described previously (Isidorov et al., 2011; Isidorov et al., 2015). Briefly, $10 \mathrm{~g}$ of honey were diluted in 50 $\mathrm{ml}$ of water and filtered through C18 extraction discs (Mallinckrodt Baker Inc.). The adsorbed compounds were eluted with $50 \mathrm{~mL}$ of diethyl ether. The solvent was evaporated and 220 $\mu \mathrm{L}$ of pyridine and $80 \mu \mathrm{L}$ of BSTFA/TMCS was added to the dry residue. The reaction mixture was sealed and heated for $0.5 \mathrm{~h}$ at $60^{\circ} \mathrm{C}$ to obtain trimethylsilyl derivatives. The TMS derivatives and identification were separated as 
described above.

\section{Microorganisms and culture media}

The antimicrobial activity of aliphatic hydroxy and dicarboxylic acids was tested against Staphylococcus aureus PCM 2267 (PCM, Polish Collection of Microorganisms), Bacillus subtilis ATCC 6634 (American Type Culture Collection), B. cereus ATCC 14579, B. cereus F4810/72, emetic reference strain, $B$. thuringiensis IS5056, Paenibacillus larvae LMG 9820 (Belgian Coordinated Collection of Microorganisms), E. coli PCM 2268, Pseudomonas aeruginosa PCM 2270, and fungi Candida albicans ATCC 10231. All the microorganisms kept at $-80^{\circ} \mathrm{C}$ in the storage medium (Luria-Bertani, LB broth and glycerol at a ratio 1:1) were inoculated onto nutrient agar (bacteria) or Sabouraud agar (fungi) and incubated overnight at $37^{\circ} \mathrm{C}$.

\section{Screening for antimicrobial activity}

The antimicrobial activity of the acids was assessed by the minimal inhibitory concentration (MIC) in accordance with the Clinical and Laboratory Standard Institute protocols. Royal jelly aliphatic acids used in this study were dissolved in DMSO at a concentration of 100 $\mathrm{mM}$ and filtered with the $0.22-\mu \mathrm{m}$ pore size Rotilabo-Spitzenfilter filter. To test the antimicrobial activity of all bacteria (except $P$. larvae), the solutions were serially diluted 2 -fold in $2 x$ concentrated Mueller-Hinton broth of pH 7.0 or 5.1 (established before autoclaving with hydrochloric acid) in a U-shaped 96-well microtiter plate with a final volume of $100 \mu \mathrm{L}$ and ranged from 0.049 to $50 \mathrm{mM}$. For $P$. larvae, the solutions were serially twofold diluted in $2 x$ concentrated Mueller-Hinton broth, pH 7.2, as this bacterium does not grow in acidic medium.

The microorganisms were cultured overnight in LB broth (S. aureus, B. cereus, B. thuringiensis, $E$. coli, $P$. aeruginosa, $C$. albicans) or Mueller-Hinton broth ( $P$. larvae) at $37^{\circ} \mathrm{C}$ with shaking (200 rpm). The cultures were suspended to a final optical density of 0.2-0.3 at a wavelength of $600 \mathrm{~nm}$ measured with a V-670 spectrophotometer (Jasco, Japan).

For the assay, $100 \mu \mathrm{L}$ of the bacterial suspen- sions was added to each well in the microtiter plate containing diluted acids and incubated for 48 hours ( $P$. larvae) or overnight (the rest of the microorganisms tested) at $37^{\circ} \mathrm{C}$. To obtain comparable data, all the bacteria were treated under the same conditions. The MIC values were determined as the lowest concentration of the acids in the wells with no bacterial growth observed visually. All the tests were carried out in quadruplicate. Microorganisms cultured in LB or Mueller-Hinton broth, as appropriate, without the acids were applied as a positive control, while the LB or Mueller-Hinton broth supplemented with $10 \%$ DMSO was used as a solvent control.

\section{RESULTS}

Acidic fraction extracted from lyophilised royal jelly by diethyl ether included 28 TMS derivatives of $C_{8^{\prime}} C_{10^{\prime}} C_{12}$ and $C_{14}$ hydroxyacids whose share in the total ion current was $91.8 \%$. In accordance with Melliou and Chinou (2005) and our previous data (Isidorov et al, 2009; 2012), the most abundant the identified compounds were 10-HDA, 10-HDAA, 2-DecDA, and 3,10-dihydroxydecanoic acid (the total list of identified compounds is presented in Tab. 1S in the Supplementary Online Material).

The presence of aliphatic acids characteristic of $\mathrm{RJ}$, the larval food of the honeybee (Apis mellifera L.), was demonstrated recently in different honeys from different countries (Isidorov et al., 2011; 2015). In this study we present the typical chromatograms (previously non published) of acidic fractions extracted from the representatives of genuine honey and herbhoney. Fig. 1 shows a fragment of typical chromatograms of multifloral and pine herbhoney TMS derivatives. Besides the peaks of phenol carboxylic acids, the chromatograms also showed clear signals of hydroxy acids and unsaturated dicarboxylic acids that were detected in the royal jelly extract. The share of $C_{8}-C_{10}$ royal jelly acids in the total ion current was $26.8 \%$ and $36.6 \%$ in the acidic fraction of multifloral and pine herbhoney, respectively.

The antimicrobial activities of the aliphatic 


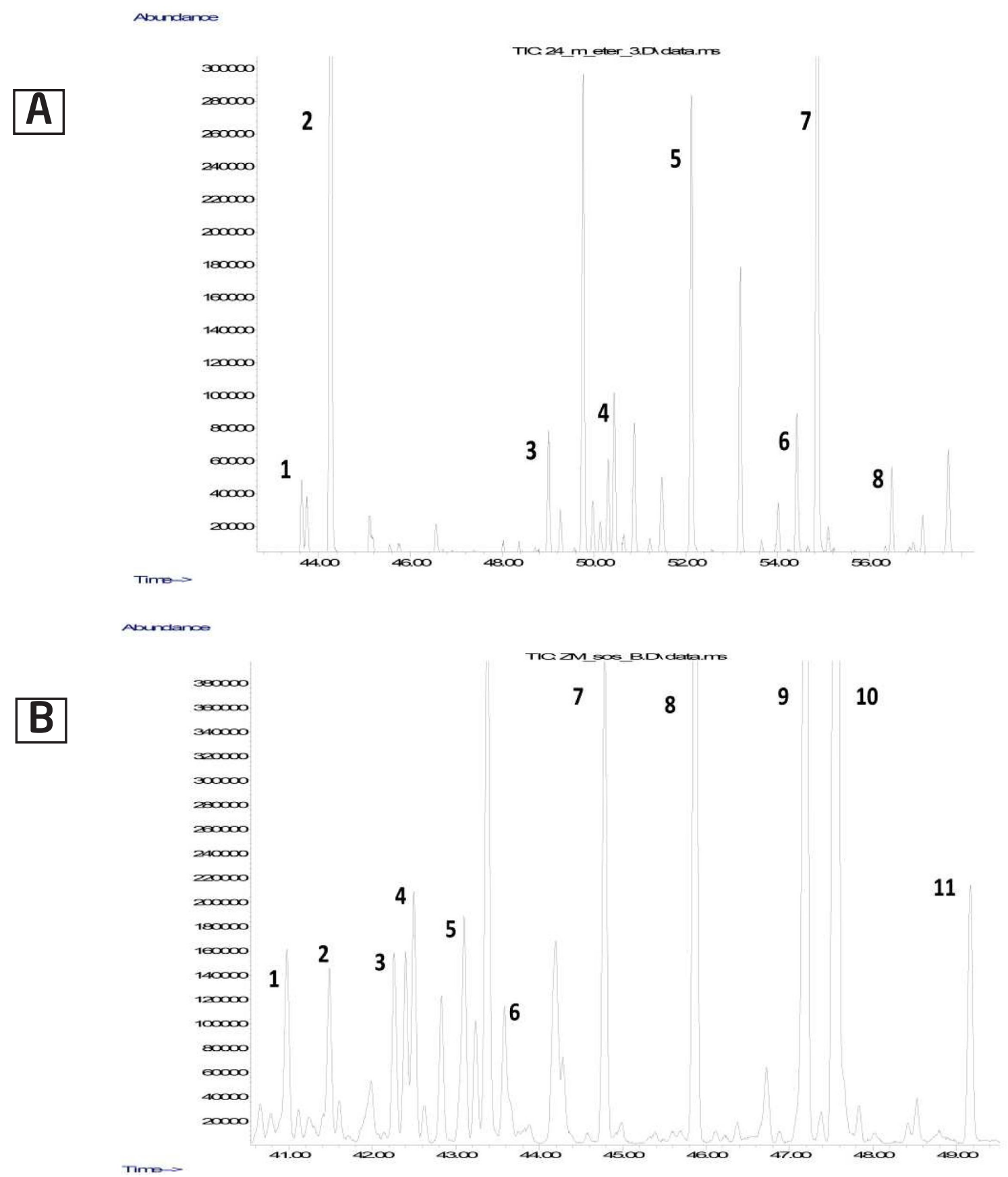

Fig. 1. Part of chromatograms of TMS derivatives of acids extracted from multifloral honey $(A)$ and pine herbhoney (B).

A: (1) 8-hydroxyoctanoic acid, (2) 4-hydroxybenzeneacetic acid, (3) 9-hydroxydecanoic acid, (4) 10-hydroxydecanoic acid, (5) 10-hydroxy-2-decenoic (10-HDA) acid, (6) p-coumaric acid, (7) 2-decene-1,10-dioic acid, (8) 3,10-dihydroxydecanoic acid (the extract also contains trace amounts of 7-hydroxyoctanoic, 2-octene-1,8-dioic, 3-hydroxydecanoic, and 9-hydroxy-2-decenoic acids).

B: (1) 2-octene-1,8-dioic acid, (2) 8-hydroxyoctanoic acid, (3) 9-hydroxy-2-decenoic acid, (4) - homovanillic acid, (5) 9-hydroxydecanoic acid, (6) 10-hydroxydecanoic acid, (7) 10-hydroxy-2-decenoic (10-HDA) acid, (8) sebacic acid, (9) $p$-coumaric acid, (10) 2-decene-1,10-dioic acid, (11) 3,10-dihydroxydecanoic acid (the extract also contains trace amounts of 7-hydroxyoctanoic, and 3-hydroxydecanoic acids). 
Table 1. acids typical of RJ were tested against the most Antimicrobial activity of some of the royal jelly acids and the acidic fraction extracted from lyophilised RJ at $\mathrm{pH} 7.0$

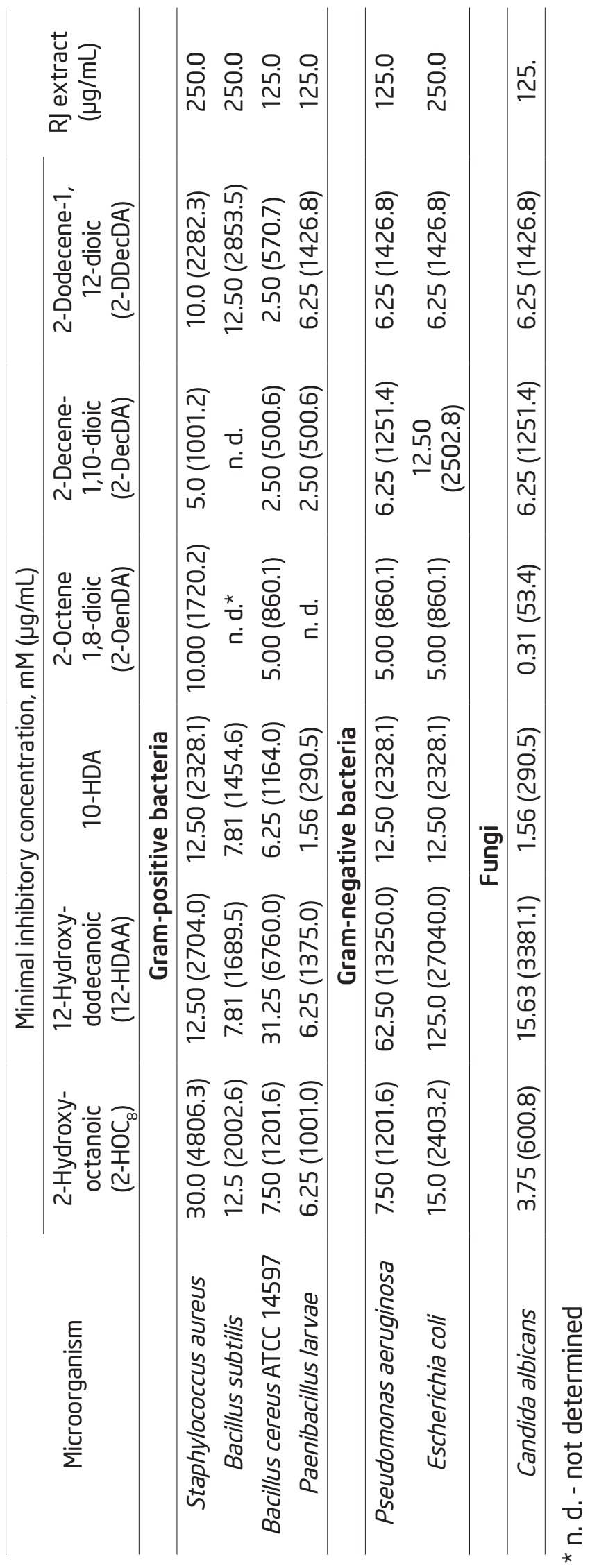
known human pathogens associated with food and involved in such food toxicity or intestinal infections as gram-positive staphylococci and bacilli. These are represented in our study by S. aureus, Bacillus cereus, an emetic $B$. cereus reference strain F4810/72 and gram-negative bacilli, e.g. E. coli and $P$. aeruginosa. In addition, we expanded the number of tested bacteria by adding $B$. subtilis, a model gram-positive organism, and $B$. thuringiensis, representing bacteria often used as bio-insecticides. Considering the increased numbers of American foulbrood among honey bees (Skubida et al., 2014), we also tested the antimicrobial effect of $\mathrm{RJ}$ acids against $P$. larvae, an etiological agent of this disease. In this study, we used strain $P$. larvae LMG 9820. To have a global view of the antimicrobial spectra of the chemicals used in the study, we also tested their activity against pathogenic fungi using a C. albicans strain.

To test the antimicrobial activity of the selected RJ acids, we used the tube dilution assays. The sensitivity of microbes were tested under neutral and slightly acidic conditions. As can be seen from data in Tables 1 and 2, the tested acids demonstrated higher activity in experiments with acidic nutrient media.

\section{DISCUSSION}

The inhibitory activity of RJ against both grampositive and gram-negative bacteria had been demonstrated many years ago by McCleskey \& Melampy (1938), but their nature and the chemical composition of this honey bee product were not established for a long time. At the end of the 1950s, the aliphatic 10-hydroxy2-decenoic acid (10-HDA) was identified as the main component of diethyl ether extracts from RJ (Butenandt \& Rembold, 1957; Barker et al., 1959). At the same time, the biological properties of RJ and its constituents were investigated, particularly the antimicrobial action of 10-HDA. Barker et al. (1959) stated that this hydroxy acid showed little or weak activity against a representative range of bacteria and fungi (the antibacterial assays were performed 
Table 2.

Antimicrobial activity of some of the royal jelly acids and the acidic fraction extracted from lyophilised RJ at pH 5.1

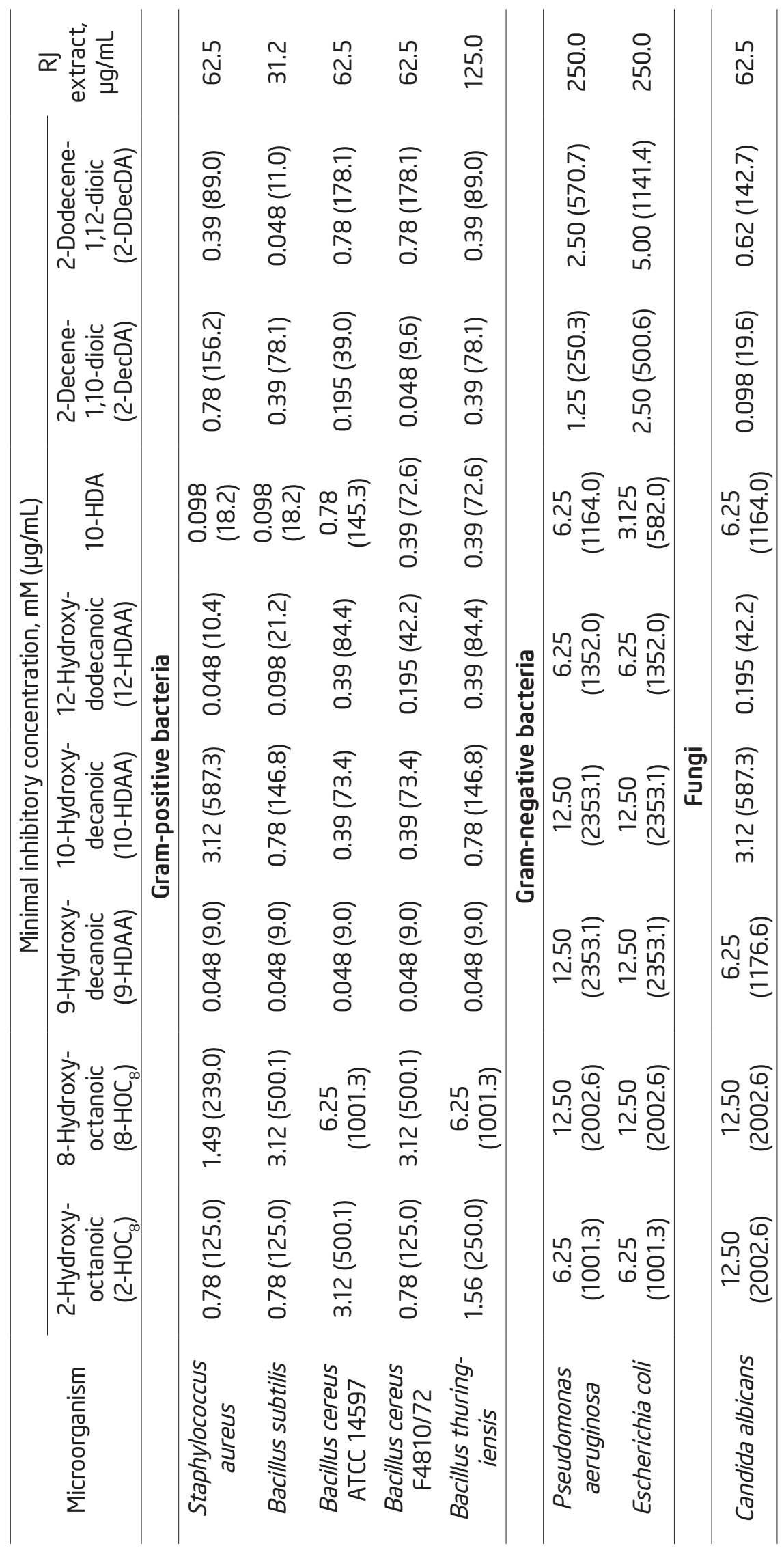


by Glaxo Ltd.). In contrast, at the same time, another working group had demonstrated the high activity of 10-HDA against many bacteria and fungi (Blum et al., 1959).

This discrepancy is supposed to be related to the differences in antimicrobial assay conditions, namely, the acidity of nutrient medium. According to McCleskey and Melampy (1938), the sterilisation of test cultures required only a few minutes at a natural acidity of $\mathrm{RJ}(\mathrm{pH}$ 4.6), but required two days at $\mathrm{pH}$ 7.0. Blum et al. (1959) had observed high bactericidal 10-HDA activity under slightly acidic conditions, but after neutralization, the activity was considerably lower. To definitively ascertain the influence of acidity (i.e. ionisation state of tested acids) on the antimicrobial activity of RJ acids, we performed two series of experiments with the neutral and acidic nutrient media.

As can be seen from Tab. 1, which presents the results of antibacterial assays under neutral conditions, the majority of the tested acids demonstrated only weak antibacterial activity (MIC $>1000 \mu \mathrm{g} / \mathrm{mL}$ ). Moderate action of 10-HDA against $P$. larvae and $C$. albicans as well as unsaturated dicarboxylic acids 2-DecDA and 2-0enDA against tested gram-positive bacteria was observed. Another unsaturated dicarboxylic acid, 2-DodecDA (known as traumatic acid), also moderately inhibited the growth of $B$. cereus with MIC 570 $\mu / \mathrm{gL}$.

In agreement with observations by Blum et al. (1959), 10-HDA and RJ acids demonstrated much higher activity against bacteria and fungi when acidification of the nutrient medium was adjusted to $\mathrm{pH}$ 5.1, i.e. typical acidity of genuine honeys (Fyfe et al., 2017). Tab. 2 presents the MIC values, which as a rule are an order of magnitude lower than that detected under neutral conditions in Tab. 1 and higher inhibition was observed in the assays with 9-HDAA against gram-positive bacteria. Interestingly, an emetic $B$. cereus reference strain F4810/72 demonstrated the highest susceptibility in relation to nearly all tested acids. Also remarkable, the growth inhibition of the diethyl ether extract of lyophilised royal jelly (its acidic fraction) was more pronounced under both neutral and acidic conditions, than separate acids found in this honey bee product. This testifies to a significant synergistic effect of different RJ extract components.

Overall, 47 hydroxy and dicarboxylic acids were registered in crude royal jelly (Isidorov et al., 2012). Ten acids characteristic of this bee product were identified in different quantities and in different combinations in the analysed honey and herbhoney samples: saturated 7- and 8-hydroxyoctanoic, 3-, 9- and 10-hydroxydecanoic, and 3,10-dihydroxydecanoic acids, as well as unsaturated 9-hydroxy-2-decenoic, 10-hydroxy-2-decenoic, 2-octene-1,8-dioic, 2-decene-1,10-dioic acids (Isidorov et al., 2011; 2015). One of them, 2-DecDA was also detected in New Zealand manuka, kanuka and white clover unifloral honeys in concentrations from 3.5 to $181.2 \mu \mathrm{g} / \mathrm{g}$ (Tan et al., 1988). Recently, 2-decenedioic acid and its glycoside were investigated in some Scottish honeys, but the exact chemical structures of the components were not determined (Fyfe et al., 2017).

The quantity of the aliphatic royal jelly acids in different samples of genuine honey and herbhoney varied from 6 to $209 \mu / g / n=65$; Isidorov et al., 2012, and unpublished data). It was proposed that RJ components produced by the mandible and hypopharyngeal glands of worker bees enter the honey at the time of nectar processing (Isidorov et al., 2011). Hence, the content of these bee-derived compounds varies depending on the bee family's physiological conditions i.e. number of young workers capable of participating in nectar processing and accessibility of protein-containing forage, which is a precursor of RJ in workers.

The combination of data presented above concerning the antibacterial activity of RJ acids and their content in honey (Isidorov et al., 2011; Isidorov et al., 2015) allows us to conclude that they are just "unknown compounds of bee origin" with bacteriostatic or bactericidal activity (Bogdanov, 1997; Kwakman et al., 2010a). RJ acids may influence microorganisms individually or participate in additive/synergistic effects with other antimicrobial agents such as hydrogen peroxide, methylglyoxal, polyphenols and the bee protein defensin-1. 


\section{ACKNOWLEDGEMENTS}

This work was performed in the framework of task S/ZWL/1/2014 of Białystok University of Technology (V.I.) as well as the Department of Natural Product Chemistry of Białystok University (S.W.), and supported from the funds of the Polish Ministry of Science and Higher Education under project Specific Scientific Equipment No. 8636/E-342/SPUB/2016/1 (I.S.).

\section{REFERENCES}

Aljadi, A.M., \& Yusoff, K. M. (2003). Isolation and identification of phenolic acids in Malaysian honey with antibacterial properties. Turkish Journal of Medicine, 33, 229-236.

Al-Waili, N. S., Salom, K., Butler, G., \& Al Ghamdi, A. A. (2011). Honey and microbial infections: A review supporting the use of honey for microbial control. Journal of Medicinal Food, 14, 1079-1096. D0l:10.1089/ jmf.2010.0161

Barker, S. A., Forster, A. B., Lamb, D. C., \& Hodgson, N. (1959). Identification of 10-hydroxy- $\Delta^{2}$ - decenoic acid in royal jelly. Nature, 183, 996-997. DOl: 10.1038/18399a0

Blum, M. S., Novak, A. F., \& Taber, S. (1959). 10-Hydroxy- $\Delta^{2}$-decenoic acid, an antibiotic found in royal jelly. Science, 130, 452-453.

Bogdanov, S. (1997). Nature and origin of the antibacterial substances in honey. LebensmittelWissenschaft und Technologie, 30, 748-753. DOl: 10.1006/fstl.1997.0259

Brudzinski, K. (2006). Effect of hydrogen peroxide on antibacterial activity of Canadian honeys. Canadian Journal of Microbiology, 52, 1228-1237.

Brudzinski, K., Abubaker, K., St-Martin, L., \& Castle., A. (2011). Re-examining the role of hydrogen peroxide in bacteriostatic and bactericidal activities of honey. Frontiers in Microbiology, 2, 213-218. D0l: 10.3389/ fmicb.2011.00213
Brudzinski, K., \& Sjaarda, C. (2015). Honey glycoproteins containing antimicrobial peptides, Jelleins of the major royal jelly protein 1, are responsible for the cell wall lytic and bactericidal activities of honey. Plos One 1044):e0120238. DOl: 10.1371/journal. pone.0120238

Brudzynski, K., Miotto, D., Kim, L., Sjaarda, C., Maldonado-Alvarez, L., Fukś, H. (2017). Active macromolecules of honey form colloidal particles essential for honey antibacterial activity and hydrogen peroxide production. Scientific Reports, 7,7637. D01:10.1038/ s41598-017-08072-0

Bučeková, M., \& Majtán, J. (2016). The MRJP1 honey glycoprotein does not contribute to the overall antibacterial activity of natural honey. European Food Research \& Technology, 242, 625-629. D0l: 10.1007/s00217-016-02665-5

Butenant, A., \& Rembold, H. (1957). Über den Weiselzellenfuttersaft der Honig Biene. Zeitschrift für Physikalische Chemie, 308, 285-299.

Core, E. J., \& Schmidt, G. (1979). Useful procedures for the oxidation of alcohols involving pyridinium dichromate in aprotic media. Tetrahedron Letters, 20,399402. DOl: 10.1016/S0040-4049(01)93515-4

Fidaleo, M., Zuorro, A., \& Lavecchia, R. (2010). Honey: a natural antimicrobial agent against foodborne pathogens? Journal of Biotechnology, 150S, S298. DOl: 10.1016/j.jbiotec.2010.09.253

Fyfe, L., Okoro, P., Paterson, U., Coyle, Sh., McDougall, G. J. (2017). Compositional analysis of Scottish honeys with antibacterial activity against antibiotic-resistant bacteria reveals novel antimicrobial components. LWT - Food Science \& Technology, 79, 52-59. doi.org/10.1016/j.lwt.2017.01.023

Giles, S. L., \& Laheij, R. J. F. (2017). Successful treatment of persistent Clostridium difficile infection with Manuka honey. International Journal of Antimicrobial Agents, 49, 522-523. doi.org/10.1016/j.jjantimicag.2017.02.005

Grecka, K., KuŚ, P. M., Worobo, R. W., \& Szweda, P. 
(2018). Study of the anti-staphylococcal potential of honeys produced in Northern Poland. Molecules, 23, 260. D01:10.3390/molecules23020260

Isidorov, V.A. (2015). Identification of Biologically and Environmentally Significant Organic Compounds. Mass Spectra and Retention Indices Library of Trimethylsilyl Derivatives. PWN, Warszawa. 429 pp.

Isidorov, V. A., Czyżewska, U., Isidorova, A. G., \& Bakier, S. (2009). Gas chromatographic and mass spectrometric characterization of the organic acids extracted from some preparations containing lyophilized royal jelly. Journal of Chromatography B, 877,37763780. DOl: 10.1016/j.jchromb.2009.09.016

Isidorov, V. A., Czyżewska, U., Jankowska, E., \& Bakier, S. (2011). Determination of royal jelly acids in honey. Food Chemistry, 124, 387-391. D0l: 10.1016/j.foodchem.2010.06.044

Isidorov, V. A., Bakier, S., \& Grzech, J. (2012). Gas chromatographic-mass spectrometric investigation of volatile and extractable compounds of crude royal jelly. Journal of Chromatography B, 885-886, 109116. DOl: 10.1016/j.jchromb.2011.12.025

Isidorov, V. A., Bagan, R., Bakier, S., \& Swiecicka, I. (2015). Chemical composition and antimicrobial activity of Polish herbhoneys. Food Chemistry, 771, 84-88. DOl: 10.1016/j.foodchem.2014.08.112

Kwakman, P. H. S., te Velde, A. A., de Boer, L., Vandenbrouke-Grauls, Ch. M. J. E., Zaat, S. A. J. (2010a). Two major medical honeys have different mechanisms of bactericidal activity. PLoS One, 6, e 17709. DOl: 10.1371/journal.pone.0017709

Kwakman, P. H. S., te Velde, A. A., de Boer, L., Speeijer, D., Vandenbrouke-Grauls, Ch. M. J. E., Zaat, S. A. J. (2010b). How honey kills bacteria. The FASEB Journal, 24, 2567-2582, DOl: 10.1096/fj.09-150789

Lee, S. K., \& Lee, H. (2016). Antibacterial activity of solvent fractions and bacterial isolated of Korean domestic honey from different floral sources. Food Science and Biotechnology, 25, 1507-1512. DOl:10.1007/s10068-016-0234-0
Mavric, E. , Wittmann, S., Barth, G., \& Henle, T. (2008). Identification and quantification of methylglyoxal as the dominant antibacterial constituent of Manuka (Leptospermium scoparium) honeys from New Zealand. Molecular Nutrition \& Food Research, 52, 483489. DOl: 10.1002/mnfr.200700282

McCleskey, C. S., \& Melampy, R. M. (1938). Bactericidal activity of "Royal Jelly" of honey bees. Journal of Microbiology, 38, 324.

Melliou, E., \& Chinou, I. (2005). Chemistry and bioactivity of royal jelly from Greece. Agricultural and Food Chemistry, 53, 8987-8992. D0l: 10.1021/jf051550p

Mizrahi, H., \& Lensky, Y. (Eds.). (1996). Bee products: Properties, applications and apitherapy. NY: Plenum Press.

Moore, O. A., Smith, L. A., Campbell, F., Seers, K., McQuay, H. J., Moore, R. A. (2001). Systematic review of the use of honey as a wound dressing. BMC Complementary \& Alternative Medicine, 1, 2-7. http://www. biomedcentral.com/1472-6882/1/2

Russell, K. M., Molan, P. C., Wilkins, A. L., \& Holand, P. T. (1988). Identification of some antibacterial constitvents of New Zealand Manuka honey. Journal of Agricultural \& Food Chemistry, 38, 10-13. D0l: 10.1021/ jf00091a002

Skubida, M., Pohorecka, K., Bober, A., \& Zdańska, D. (2014). Five-year investigation of Paenibacillus larvae expansion in Polish apiaries: Analyses of results. In: Mat. 51 th Sci. Beekeep. Conf., Szczyrk, pp. 55-56.

Sultanbawa, Y., Cozzolino, D., Fuller, S., Cusack, A., Currie, M., Smyth, H. (2015). Infrared spectroscopy as a rapid tool to detect methylglyoxal and antibacterial activity in Australian honeys. Food Chemistry, 172, 207-212. DOl: 10.1016/j.foodchem.2014.09.067

Tan, S.-T., Holland, P. T., Wilkins, A. L., \& Molan, P. C. (1988). Extractivities from New Zealand honeys. White clover, manuka and kanuka unifloral honeys. Journal of Agricultural \& Food Chemistry, 36, 453460. DOl: 10.1021/jf00081a012 
Taormina, P. .., Niemira, B. A., \& Beuchat, L. R. (2001). Inhibitory activity of honey against foodborne pathogens as influenced by the presence of hydrogen peroxide and level of antioxidant power. International Journal of Food Microbiology, 69, 217-225.

Valachová, l., Bučeková, M., \& Majtán, J. (2016). Quantification of bee-derived peptide Defensin-1 in honey by competitive enzyme-linked immunosorbent assay, a new approach in honey quality control. Czech Journal of Food Sciences, 34, 233-243. DOl: 10.17221/422/2015-cjfs

Weston, R. J., Brocklebank, L. K., \& Lu, Y. R. (2000). Identification and quantitative levels of antibacterial components of some New Zealand honeys. Food Chemistry, 70, 427-435. DOl: 10.1016/S03088146(00)00127-8 


\section{Supplementary data}

associated with the article titled: " Royal jelly aliphatic acids contribute to the antibacterial activity of honey" by Valery A. Isidorov, Stanisław Witkowski, Piotr Iwaniuk, Monika Zambrzycka and Izabela Swiecicka

\section{A. GC-MS analysis of extract from lyophilized royal jelly}

Acidic fraction of R extracted by diethyl ether was derivatised by BSTFA. The obtained solution of TMS derivatives was analysed by a GC-MS method on a HP 7890 gas chromatograph with the 5975 VL MSD Triple-Axis Detector (Agilent Technologies, USA). The apparatus was fitted with an HP-5MS fused silica column (30 m × $0.25 \mathrm{~mm}$ i.d., $0.25 \mu \mathrm{m}$ film thickness), with electronic pressure control and split/splitless injector. The latter worked at $250^{\circ} \mathrm{C}$ in the split (1:50) mode. The helium flow rate through the column was $1 \mathrm{~mL} / \mathrm{min}$. The initial column temperature was $50^{\circ} \mathrm{C}$, rising to $320^{\circ} \mathrm{C}$ at $3^{\circ} \mathrm{C} / \mathrm{min}$, and the higher temperature was maintained for $15 \mathrm{~min}$. The MSD detector acquisition parameters were as follows: the transfer line temperature was $280^{\circ} \mathrm{C}$, the MS source temperature $230^{\circ} \mathrm{C}$ and the MS quad temperature $150^{\circ} \mathrm{C}$. The electron impact mass spectra were obtained at $70 \mathrm{eV}$ of ionization energy. After integration, the fraction of separated components in the total ion current (TIC) was calculated.

To identify the separated components, both mass spectral data and calculated linear temperature-programmed retention indices $(/ T)$ were used. Mass spectrometric identification was carried out with an automatic system of GC-MS data processing supplied by NIST and home-made mass spectra libraries. The latter contains more than 1750 spectra of TMS derivatives prepared from commercial preparations of flavonoids, other phenolics, terpenoids, aliphatic acids, alcohols and carbohydrates.

Retention indices were calculated from the results of the separation $\mathrm{C}_{8}-\mathrm{C}_{40} n$-alkanes solutions in hexane and the TMS derivatives. The obtained $I^{T}$ values were compared with NIST collection (NIST 2013) as well as with the authors' previously published data (Isidorov et al., 2009; Isidorov et al., 2014a; 2014b; Isidorov, 2015). Identification was considered reliable if the results of a computer search in the mass spectra library were confirmed by the experimental $I^{T}$ values, i.e., if their deviation from the averaged literature values did not exceed $\pm 10 \mathrm{u.} \mathrm{i.} \mathrm{(inter-laboratorial} \mathrm{deviation} \mathrm{for} \mathrm{low}$ polar stationary phases). Apart from the semi-quantitative composition (total ion current fraction) of extract, Tab. 1 contains some analytical parameters that were used to confirm the results of identification (calculated and literature retention indices, $\mathrm{m} / \mathrm{z}$ values of the most intensive ions in the mass spectra, and the mass number of molecular ions $\mathrm{M}^{+}$, if detected in the mass spectra). The list of identified substances includes 28 TMS derivatives of $C_{8}, C_{10}, C_{12}$ and $C_{14}$ hydroxyacids whose share in the total ion current is $91.8 \%$. 
Table 1S.

Relative chemical composition (\% of TIC) of ether extract from lyophilized royal jelly

\begin{tabular}{|c|c|c|c|c|c|}
\hline Compound, TMS & $\mathrm{RI}^{\mathrm{Exp}}$ & $\mathrm{R}^{L^{\text {it }}}$ & Target ions, m/z & $M+$ & $\%$ \\
\hline Lactic acid & 1074 & 1074 & 73,117,147,191,190 & - & 0.07 \\
\hline Benzoic acid & 1247 & 1250 & $179,105,135,77,194$ & 194 & 0.01 \\
\hline Octanoic acid & 1270 & 1266 & $201,75,73,117,129$ & - & 0.03 \\
\hline Glycerol & 1294 & 1293 & $147,205,73,218,117$ & - & 0.05 \\
\hline Nicotinic acid & 1295 & 1296 & $180,106,136,78,51$ & - & 0.02 \\
\hline Pyrocatechol & 1322 & 1330 & $73,254,199,75,147$ & 254 & trace \\
\hline Succinic acid & 1325 & 1321 & $147,73,247,75,129$ & - & 0.01 \\
\hline 2-Hydroxyoctanoic acid & 1472 & 1468 & $215,75,73,81,131$ & - & 0.09 \\
\hline 3-Hydroxyoctanoic acid & 1483 & 1486 & $73,147,173,233,247$ & - & 0.3 \\
\hline 4-Hydroxy methylbenzoate & 1494 & 1494 & $209,224,193,135,73$ & 224 & 0.02 \\
\hline 7-Hydroxyoctanoic acid & 1558 & 1555 & $117,73,75,217,147$ & - & 0.8 \\
\hline $\mathrm{NN}$ & 1604 & - & $117,147,73,230,81$ & - & 0.01 \\
\hline 8-Hydroxyoctanoic acid & 1628 & 1624 & $147,73,289,75,55$ & 304 & 5.6 \\
\hline 4-Hydroxybenzoic acid (paraben) & 1632 & 1636 & $267,223,183,282,73$ & 282 & 0.01 \\
\hline 4-Methylheptanedioic acid & 1654 & 1653 & $117,73,75,217,274$ & - & 0.01 \\
\hline 3-Hydroxydecenoic acid? & 1661 & - & $147,73,75,233,199$ & - & trace* \\
\hline 3-Hydroxydecanoic acid (3-HDA) & 1669 & 1667 & $73,147,233,201,275$ & 332 & 1.5 \\
\hline 8-Hydroxy-2-octenoic acid & 1677 & 1675 & $147,73,287,95,81$ & 302 & 0.07 \\
\hline Octanedioic (suberic) acid & 1710 & 1706 & $73,75,187,303,147$ & - & 0.03 \\
\hline NN & 1726 & - & $303,73,75,147,213$ & - & 0.01 \\
\hline NN & 1737 & - & $73,131,303,117,147$ & - & 0.01 \\
\hline 9-Hydroxydecanoic acid & 1750 & 1750 & $117,73,217,317,147$ & 332 & 0.5 \\
\hline NN & 1759 & - & $145,73,230,147,287$ & - & 0.02 \\
\hline 4-Hydroxy hydrocinnamic acid & 1766 & 1764 & $179,193,310,73,75$ & - & 0.01 \\
\hline Vanillic acid & 1775 & 1776 & $297,312,73,267$ & 312 & trace \\
\hline 3,4-Dihydroxy-2-phenylethanol & 1781 & 1781 & $267,370,193,179,73$ & 370 & 0.01 \\
\hline 8-Hydroxy-2-decenoic acid & 1786 & 1784 & $131,73,211,315,81$ & 330 & 0.02 \\
\hline Glycerol-1-phosphate & 1798 & 1796 & $357,299,73,356,315$ & - & 2.7 \\
\hline 9-Hydroxy-2-decenoic acid & 1802 & 1801 & $117,73,147,286,315$ & 330 & trace \\
\hline 10-Hydroxydecanoic acid (10HDAA) & 1822 & 1820 & $317,73,75,147,227$ & 332 & 15.2 \\
\hline NN & 1836 & - & $289,73,147,171,199$ & - & 0.1 \\
\hline$\alpha$-Fructofuranose & 1846 & 1846 & $217,73,437,147,525$ & - & 0.02 \\
\hline 10-Hydroxy-2-decenoic acid (10-HDA) & 1876 & 1875 & $147,315,73,81,75$ & 330 & 52.0 \\
\hline Decanedioic (sebacic) acid & 1907 & 1904 & 73,331,75,215,129 & - & 4.1 \\
\hline 10-Hydroxydodecanoic acid & 1931 & 1931 & $331,131,73,75,217$ & 360 & 0.4 \\
\hline 3,9-Dihydroxydecanoic acid & 1938 & 1936 & $73,117,147,305,233$ & - & 0.4 \\
\hline 11-Hydroxydodecanoic acid & 1946 & 1944 & $117,73,147,204,217$ & 358 & 0.7 \\
\hline 2-Decene-1,10-dioic acid & 1960 & 1958 & $73,75,136,164,119$ & 344 & 4.5 \\
\hline 10-Hydroxy-2-dodecenoic acid & 1991 & - & $329,131,73,253,300$ & & 0.04 \\
\hline NN & 1997 & - & $117,73,253,343,314$ & - & 0.2 \\
\hline 3,10-Dihydroxydecanoic acid (3,10-DDA) & 2011 & 2011 & $73,147,233,405,75$ & 420 & 8.3 \\
\hline 12-Hydroxydodecanoic acid & 2018 & 2016 & $345,73,329,147,255$ & 360 & 0.3 \\
\hline NN & 2025 & - & $317,73,318,147,129$ & - & 0.2 \\
\hline$\beta$-Glucopyranose & 2030 & 2029 & $204,191,73 \ldots . .525$ & - & 0.02 \\
\hline Hexadecanoic acid & 2054 & 2051 & $313,73,75,129,132$ & 328 & 0.06 \\
\hline
\end{tabular}


12-Hydroxy-2-dodecenoic acid NN

3-Hydroxydecanedioic acid Dodecanedioic acid

3,10-Dihydroxydodecanoic acid

3,11-Dihydroxydodecanoic acid NN (dihydroxydodecanoic acid?) $\mathrm{NN}$

10,11-Dihydroxydodecanoic acid

11,12-Dihydroxydodecanoic acid?

3,12-Dihydroxydodecanoic acid

14-Hydroxytetraceadecanoic acid? Oleic acid

Octadecanoic acid

3,13-Dihydroxytetraceadecanoic acid $n$-Heptacosane n-Nonacosane

$\begin{array}{lcccc}2069 & 2070 & 343,147,73,253,315 & 358 & 0.2 \\ 2071 & - & 315,73,147,225,403 & - & 0.5 \\ 2090 & 2088 & 73,147,233,217,303 & - & 0.05 \\ 2100 & 2099 & 359,73,75,217,234 & - & 0.1 \\ 2110 & 2111 & 73,131,147,233,419 & - & 0.02 \\ 2126 & 2125 & 117,73,147,305,233 & 448 & 0.4 \\ 2133 & - & 331,73,117,147,433 & 448 & 0.03 \\ 2138 & - & 117,73,75,373,357 & - & 0.05 \\ 2152 & 2151 & 331,73,332,147,433 & 448 & 0.2 \\ 2172 & 2172 & 73,103,271,129,217 & - & 0.1 \\ 2198 & 2198 & 147,73,233,433,189 & - & 0.1 \\ 2214 & - & 345,73,147,75,346 & - & \text { trace } \\ 2222 & 2218 & 339,73,75,117,55 & 354 & \text { trace } \\ 2250 & 2250 & 73,147,73,129,132 & 356 & 0.03 \\ 2316 & 2314 & 73,117,147,305,233 & - & 0.01 \\ 2700 & 2700 & 57,71,85,43,41 & - & 0.01 \\ 2900 & 2900 & 57,71,85,43,41 & - & 0.01\end{array}$

*trace - below $0.01 \%$ of TIC.

\section{REFERENCES}

Isidorov, V. A., Brzozowska, M., Czyżewska, U., \& Glinka, Ł. (2009). Gas chromatographic investigation of phenylpropenoid glycerides from aspen (Populus tremula L.) buds. Journal of Chromatography A, 1798-7199. 196-201. DOl: 10.1016/j.chroma.2008.05.038

Isidorov, V., Szczepaniak, L., \& Bakier, S. (2014a). Rapid GC/MS determination of botanical precursors of Eurasian propolis. Food Chemistry, 142, 101-110. D0l: 10.1016/j.foodchem.2013.07.032

Isidorov, V., Szczepaniak, L., Wróblewska, A., Pirożnikow, E., Vetchinnikova, L. (2014b). Gas chromatographicmass spectrometric examination of chemical composition of two Eurasian birch (BetulaL.) bud exudates and its taxonomical implication. Biochemical Systematics and Ecology, 52,41-48. DOl: 10.1016/j.bse.2013.12.008

Isidorov, V.A. (2015). Identification of Biologically and Environmentally Significant Organic Compounds. Mass Spectra and Retention Indices of Trimethylsilyl Derivatives. PWN, Warsaw, 430 pp.

NIST Chemistry WebBook (2013). National Institute of Standards and Technology, Gaithersburg, MD 20899. http://webbook.nist.gov.chemistry. 